\title{
Robimson-Patman Act Regulation of Intraenterprise Pricing
}

\author{
Howard Shelanski $\uparrow$
}

The Robinson-Patman Act prohibits sellers from charging different customers different prices for the same goods. Whether a seller's wholly owned subsidiaries count as "different purchasers" under the Act is unclear. The statute and its legislative history are ambiguous, and the case law reveals that federal courts have taken two approaches: the dominion-and-control test, which allows differential pricing to subsidiaries only when they are closely controlled by the parent firm, and the single-entity rule, which always treats parent and subsidiary as a unitary firm and exempts sales between them from the Act. Although the trend in the federal courts has been toward the single-entity rule, the circuits remain divided. This Comment presents two new arguments for adopting the single-entity rule. First, intraenterprise pricing serves important functions in firm management, and the costs of interfering with those functions could far exceed the Act's intended benefits. Second, this Comment uses transaction-cost analysis, bolstered by original empirical research, to show that even when a firm does not maintain tight dominion and control over a subsidiary, it may nonetheless need to exercise such control over specific transactions. The dominion-and-control test fails to appreciate the need for such control because of its emphasis on firm-level, as opposed to transaction-level, indicators of control, and can therefore result in costly and unwarranted regulation. The dominion-and-control test should therefore be abandoned, and the single-entity rule should be adopted.

\section{INTRODUCTION}

The Robinson-Patman Act ${ }^{1}$ prohibits firms from charging different purchasers different prices for the same goods. Critics contend that enforcement of the Act often yields inefficient and counterproductive

† B.A. 1986, Haverford College; J.D. candidate 1992, Boalt Hall School of Law, University of California, Berkeley; Ph.D. candidate 1992 (Economics), University of California, Berkeley.

I wish to thank Professor Einer Elhauge, Professor Herbert Hovenkamp, Caroline Lee, Wendy Nicholson, Steve Rosen, Professor Daniel Rubinfeld, Professor Pablo Spiller, Nina Webb, and Professor Ohiver Williamson for helpful comments and advice. I thank the John M. Olin Foundation for financial support.

1. 15 U.S.C. $\S 13($ a) (1988). The Act was passed in 1936 as an amendinent to $\S 2$ of the Clayton Act. 
outcomes, and public enforcement agencies have paid little attention to the statute for the past decade. ${ }^{2}$ Nevertheless, the possibility of private suits requires firms to remain attentive to the Act's provisions. This Comment addresses one kind of pricing behavior that plaintiffs challenge under the Act: the sale of goods from a parent firm to a wholly owned subsidiary at prices below those charged to outsiders for the same goods.

Consider a multidivisional, or "M-form,"3 firm with diverse divisions and subsidiaries. Suppose the parent firm sells an imput to one of its subsidiaries at a lower price than it charges outside firms for the same component. If the outside purchaser challenges the differential pricing in court, what will be the result? Has the firm violated the RobinsonPatman Act by charging the two customers different prices, or is intraenterprise pricmg 4 beyond the Act's scrutiny?

Positive legal analysis offers no clear answer to the questions posed above. Accordingly, the problem becomes normative: should the Act, as a matter of sound policy, apply to parent-subsidiary sales? ${ }^{5}$ Althougli courts and commentators have debated this question, it remains unresolved-the federal circuit courts are split, and the Umited States Supreme Court ultimately may have to resolve the issue. ${ }^{6}$ Participants in

2. Herbert Hovenkamp, Economics and Federal ANTtTrust LAW 347 (1985) (describing the effects and criticisms of the Act).

3. Modern, diversified firms are often organized as inultidivisional (M-form) enterprises. For the best discussion of the developinent of the M-form firm, see ALFRED D. ChaNDLER, JR., STRATEGY AND STRUCTURE: CHAPTERS IN THE HISTORY OF THE INDUSTRIAL ENTERPRISE (1962) (examining the developinent of corporate structures among inajor American companies). The essence of the $M$-form structure is that central manageinent handles long-term planning and major operating decisions, while divisions or subsidiaries manage daily production and business operations. Policy implementation and responsibility for particular markets or product lines is delegated to divisional managers.

By $1976,95.8 \%$ of 620 firms responding to a survey of the largest 1000 manufacturing firms were organized in the M-form structure. James S. Reece \& William R. Cool, Measuring Invesiment Center Performance, 56 HARv. Bus. REV., May-Jım. 1978, at 28, 29 (examining the methods of organization einployed by "Fortime 1000 " firms). Moreover, about $80 \%$ of such firms engaged in the transfer of goods between organizational subunits. ROBERT G. ECCLES, THE TRANSFER Pricing Problem: A Theory for Practice 2 (1985) (discussing numerous surveys of the pricing policies of inajor manufacturing firms).

Divisionalization is common among American corporations. Many efficiencies flow from decentralizing various operations and placing them under the responsibility of a lower level of manageinent. Profit centers are divisions that nsually produce a market product. Headquarters evaluates a profit center's performance primarily on its profitability. See, e.g., id.

4. I will use the terms "transfer pricing" and "intraenterprise pricing" interchangeably. They refer to pricing between any subuunts, such as divisions or subsidiaries, of the same enterprise.

5. Sales between subsidiaries may differ in structure from parent-subsidiary sales. The parent firm can exercise more control over a subsidiary than another subsidiary can. The vertical ownership relation is critical in this respect. However, the parent firm can intervene in subsidiarysubsidiary relationships on behalf of one of the parties and interject hierarchical authority into such transactions. This Comment focuses on the parent-subsidiary relationship.

6. I wish to note at the outset that Copperweld Corp. v. Independence Tube Corp., 467 U.S. 752 (1984), does not necessarily resolve the issue. Copperweld Corp. applied a per se exemption from 
the debate have advanced several arguments, and two principal views have emerged: proponents of the single-entity rule argue that the Act should never apply to parent-subsidiary sales; ${ }^{7}$ proponents of the dominion-and-control test argue that the Act should not apply when the parent maintains "dominion and control"8 over the subsidiary, but should apply where the subsidiary operates independently of the parent. ${ }^{9}$

This Comment presents two new arguments for the position that parent-subsidiary transactions should not be subject to the RobimsonPatinan Act. The first argument is that the costs of extending the Act to parent-subsidiary sales can exceed the benefits, and that there are reasons to be attentive to such trade-offs. Both the statute itself and the case law recognize limits on the Act's scope: the legislative history reveals that Congress intended to exempt internal sales from regulation, and the case law shows that courts have refused to apply the Act automatically to parent-subsidiary sales. Therefore, even though the Act demonstrates a greater concern for distributive goals than for economic efficiency, it miphicitly recognizes trade-offs between them. ${ }^{10}$

This Cominent adds substance to the cost-benefit analysis by arguing that regulating intraenterprise pricing can interfere with legitimate managerial goals and impose heavy costs on firms. Efficiency, perfornance measurement, and internal fairness considerations all can require firms to charge inside and outside customers different prices. If the Act is apphed to a firm sensitive to these considerations, it might cause the particular firm to organize less efficiently, imposing costs on both the enterprise and consumers. These costs might not be offset by any benefits for parties the Act aims to protect.

Both the simgle-entity rule and the dominion-and-control test recognize the cost-benefit problem involved in applyimg the Act. The singleentity rule avoids the problem altogether by placing parent-subsidiary sales per se beyond the Act's scope. The dominion-and-control test, on the other hand, represents an attempt to provide courts with a frainework for distinguishing legitimate management from predatory differential pricing. In so doing, it aims to shield from regulation those instances in which regulatory imterference with managerial strategy would be unduly costly for the enterprise.

$\S 1$ of the Sherman Act to so-called intraenterprise conspiracies in restraint of trade. The case does not apply to the Robinson-Patman Act. For a strong arguinent about why the two issues are conceptually distinct, see Judge Kennedy's dissent in Russ' Kwik Car Wash v. Marathon Petroleum Co., 772 F.2d 214, 221-23 (6th Cir. 1985).

7. See infra text accompanying notes 53-82.

8. See, e.g., Reines Distrib., Inc. v. Admiral Corp., 241 F. Supp. 814, 815 (S.D.N.Y. 1964) (citing use of the test by other courts).

9. See infra text accompanying notes 30-52.

10. See infra note 13 and accompanying text. 
This Cominent's second argument addresses the dominion-and-control test on its own terms and argues that it fails in its mission. The argument uses transaction-cost analysis to show that firms use internal pricing pohicies to adjust control over individual transactions ${ }^{11}$ even if the parent firm does not maintain general operating control over the subsidiary. Such selective control can be inotivated by legitimate concerns over the governance of transactions rather than by opportunistic or anticoinpetitive ends. Original enıpirical research that supports this analysis is presented.

The transaction-cost argument criticizes attempts to ineasure dominion and control through firm-level factors such as interlocking boards and shared accounting systenis. These factors fail to capture transaction-level variables that imght inake differential intraenterprise pricing efficient. Assessing the extent of a parent firm's dominion and control over individual transactions, however, is extreinely difficult, and courts cannot distinguish reasonably annong individual parent-subsidiary sales in deciding whether to apply the Act. Parent-subsidiary sales should therefore be exenipted per se from Robinson-Patnian Act scrutiny.

The Comment will proceed as follows: Part II examines the statutory language and case law to see how the Act applies to intraenterprise pricing. It then compares the coinpeting approaches to applying the Act, arguing that although the statute is not primarily concerned with efficiency, it does einbody certain cost-benefit trade-offs. Next, Part III examines the role of transfer pricing in inanaging and organizing firms and discusses the policy miphications of such pricing for the RobinsonPatnian Act. Part IV addresses the dominion-and-control test and presents the transaction-cost analysis and enipirical evidence. This is followed by a policy analysis and recommendation in Part V. Part VI concludes that courts should apply the single-entity rule rather than the dominion-and-control test to intraenterprise pricinig.

\section{II}

\section{Analysis of the Statute and CaSe Law}

\section{A. Statutory Analysis}

Section 2 of the Robinson-Patınan Act inakes it "unlawful for any person ... to discriminate in price between different purchasers of cominodities of like grade and quality ... where the effect ... may be substantially to lessen coinpetition or tend to create a inonopoly."12 Unfortunately, the Act's drafters failed to articulate whether a subsidiary

11. See infra text accompanying notes 118-49.

12. 15 U.S.C. $\$ 13(\mathrm{a})(1988)$. 
qualifies as a "different purchaser." Although the text of the Act itself leaves the status of subsidiaries unclear, an examination of the Act's purposes and legislative history can provide guidance on this point.

Congress' goal in drafting the Robinson-Patman Act was to protect sinall businesses, particularly retail grocers, that larger, inore efficient enterprises might drive out of business. ${ }^{13}$ The drafters feared that large chain stores would purchase in bulk at rates cheaper than those available to sinall retailers, forcing the small retailers out of business. They were particularly afraid that such differential pricing ${ }^{14}$ would be used to accoinphish collusive or predatory strategies. For exainple, Congress thought that to gain market share, a distributor might sell below cost in a competitive inarket and recoup its losses by charging higher prices in a different area in which it possessed market power. ${ }^{15}$

Moreover, those drafters imterested in preserving sinall busmesses worried that differential pricing could lead to "price squeezes."16 A price squeeze occurs when a purchaser pays less than its coinpetitor pays for the saine good, thereby lowering its production costs in coinparison to the coinpetitor's. The favored purchaser can then use its cost advantage to lower the market pricc of the product that it and the coinpetitor producc. The competitor is "squeezed" between the higher input costs it inust pay and the lower inarket price it inust charge, and is eventually pushed out of business. By prohibiting differential pricing, the Act seeks to prevent price squeezes.

Because a subsidiary's coinpetitor can be squeezed out if the subsidiary pays the parent less for an input than the coinpetitor does, the purposes of the Act arguably could be served by inaking subsidiaries "different purchasers." Furthermore, if the parent has market power in the transferred good, it might be able to prey on coinpetitors by selling

13. HovenKAMP, supra note 2, at 345 . It follows that Congress was not concerned with economic-welfare losses because higher consumer prices were the logical consequence of enforcing the Act. Thus, the statute had distributional rather than efficiency goals. Certain efficiencies associated with integration and unified ownership, however, may be lost if courts interfere with parent-subsidiary relations. Because the Act is deliberately distributive, not welfare increasimg, efficiency arguments alone do not appear to exempt intraenterprise behavior from the Act's scope.

14. The Act is often called a "price discrimination" statute. In fact, what it prohibits is differential pricing, not true economic price discrimination. For an excelleut discussion of this poimt, see id. at 338-54.

15. This fear is based upon questionable economic analysis. Because the distributor is already charging the profit-maximizing price in the noncompetitive market, it cannot raise net revenues by further raisimg prices in that market. Therefore, in a competitive market it cannot recoup losses caused by predation. It can, however, use supracompetitive profits in one market to fund predatory pricing in another market, at least in the short term. The resulting net profits, although more than zero, will be less than the distributor would earn without predation. It is unclear that such a strategy could result in any gain even in the long run. Withont supracompetitive profits im one market, the distributor has no slack from which to fund predatory pricing in another market.

16. See Hovenkamp, supra note $2, \S 6.12$ (discussing predatory pricing problems and the effect of the Robinson-Patinan Act). 
below cost to the subsidiary while still making an overall profit because of the higher price paid by the outsider. ${ }^{17}$

Simiply because certain applications of the statute might serve the statute's purposes, however, does not mean that those applications are warranted. Congress' distributional goals would also be served by making wholly owned divisions of a single corporation subject to the Act. Yet the legislative history inakes it clear that the Act does not apply to such entities. ${ }^{18}$ Why, then, should the Act apply when internal divisions are wholly owned, but happen to be separately incorporated? Neither the statute nor the legislative history distinguishes separately incorporated subsidiaries from integrated divisions or supphies a rationale for such a distinction when applying the statute.

The exclusion of interdivisional sales from the Act suggests that Congress recognized that enforceinent of the Act would require soine trade-offs, and that Congress was unwilling to further its distributional goals without limits. Judge Easterbrook has argued that "all statutes are compromises" and that "[n]o matter how good the end in view, achievement of the end will have some cost, and at soine point the cost will begin to exceed the benefits." 19 Statutes should therefore not apply to every possible situation that miplicates the legislature's purpose.

According to Judge Easterbrook, the extent to which courts should apply statutes to situations not expressly conteinplated by the legislature depends on two factors. First, one must consider whether the legislation was the product of interest-group lobbying or whether it was enacted purely in the public's interest. ${ }^{20}$ If the former, Judge Easterbrook argued that the constrnction ought to be extremely narrow because anything not expressly granted reflects an impled limit on the statute's apphicability. ${ }^{21}$ Second, one must consider whether the legislation extends to the point where the costs of its application begin to exceed the benefits. ${ }^{22}$

The Robinson-Patman Act is unquestionably an exainple of specialinterest legislation. It was the product of concerted lobbying by sinall grocers who feared that the greater buying power of large chain stores

17. This does not imply, however, that the parent is recouping its losses. It is simply earning a profit, albeit a lower one than it would earn if the subsidiary paid the full cost.

18. See To Amend the Clayton Act, 1935: Hearings on H.R. 8442, H.R. 4995, H.R. 5062 Before the House Comm. on the Judiciary, 74th Cong., 1st Sess. 211, 229 (1935) [hereinafter Hearings] (stating sales within same company are not reached by the Act); see also John Huddleston, Comment, Can Subsidiaries Be "Purchasers" From Their Parents Under the Robinson Patman Act? A Plea for a Consistent Approach, 63 WASH. L. REv. 957, 966 n.60 (1988) (transfers witlin a corporation are not covered by the Act because they are not considered "sales").

19. Frank H. Easterbrook, Statutes' Domains, 50 U. CH1. L. REv. 533, $540-41$ (1983).

20. Id. at 541 .

21. See id. ("In the case of interest group legislation it is most likely that the extent of the bargain ... is exhausted by the subjects of the express comproimises reflected in the statute.").

22. Id. at 543 . 
would squeeze them out of the market. ${ }^{23}$ The congressional hearings surrounding the Act clarified that the scope of the statute had certain limits ${ }^{24}$ - the legislation did not reach sales within the same company, despite the recognition that such sales could cause the very harms that the Act sought to avoid. ${ }^{25}$

Courts should be wary, therefore, about making subsidiaries different purchasers simply because doing so might further the Act's distributional goals. The legislature clearly contemplated situations in which distributive goals would be harmed but the statute nevertheless should not be apphed. To the extent that regulating parent-subsidiary sales might cause efficiency losses that outweigh the statutory benefits, it is far from clear that regulating these transactions will further the legislature's goals. Part III discusses exactly why these losses might occur. That analysis will address whether such an extension of the legislation actually does cause losses that exceed benefits.

A full analysis of the legislative intent and history of the Act is beyond the scope of this Comment. The Robinson-Patman Act, however, does not provide a definitive answer to the question of whether subsidiaries are different purchasers under the statute. The text of the Act is silent on this point, and while the Act's purposes do not discount its application to subsidiaries, the legislative history imdicates that Congress might have intended that imtraenterprise transactions fall outside of the Act's scope. Not surprisingly, the issue has been left to the courts.

\section{B. Case Law Analysis}

\section{An Early Approach}

A doctrine that had some early favor held that a parent and a separately imcorporated subsidiary should be considered distinct entities for purposes of the Robinson-Patman Act. The court im Danko v. Shell Oil $\mathrm{Co}^{26}$ stated the concept most clearly: "The fact that [the] defendant itself may own and control such filling station would not destroy the relationship of vendor and purchaser."27

The Danko court attempted to look "behind form to see who the real competitors are."28 The goal of this approach was to protect independent entities from coinpetitors who might receive advantages from firms standing in a vertical ownership relationship with thein.

23. HoveNKAMP, supra note 2 , at 345.

24. See Hearings, supra note 18, at 211, 229.

25. Id.

26. 115 F. Supp. 886 (E.D.N.Y. 1953).

27. Id. at 888 .

28. Id. (citing American Coop. Serum Ass'n v. Anchor Serum Co., 153 F.2d 907, 913-14 (7th

Cir.), cert denied, 329 U.S. 721 (1946)). 
While purporting to look beyond form, however, the court in fact adopted a very rigid rule. By refusing to consider ownership and control as factors capable of affecting the classification of parent-subsidiary transactions as vendor-purchaser transactions, the Danko court held that a buying subsidiary is virtually per se a different purchaser under the Robinson-Patinan Act. ${ }^{29}$

\section{From Danko to the Dominion-and-Control Test}

The courts in several cases decided after Danko agreed that a wholly owned subsidiary could be considered a purchaser froin the parent firm under the Act. ${ }^{30}$ These courts, however, adopted a more flexible approach, making control over the subsidiary a relevant consideration. In Baim \& Blank, Inc. v. Philco Corp. ${ }^{31}$ the district court indicated that if the parent had substantial control over the goods after they were transferred to the subsidiary, the exchange would be beyond Robinson-Patman scrutiny. ${ }^{32}$ The court reasoned that assessing whether the parent had dominion and control over the good is essential in determining whether a seller-purchaser relationship exists. ${ }^{33}$

In Reines Distributors, Inc. v. Admiral Corp. ${ }^{34}$ the court also found dominion and control relevant to whether a subsidiary is a legal purchaser from its parent firm, holding that whether a subsidiary is a "purchaser" under the Act is a question of material fact. ${ }^{35}$ The court stated that certain factors, including passage of title to the transferred goods and control over the pricing policy for goods inarketed by the subsidiary, should be considered in the factual determination. ${ }^{36}$ Despite the effort in Reines to flesh out the components of dominion and control, the court did not expressly state which factors should be considered and how their relative importance should be weighed. Thus, later courts applied the dominion-and-control test in varying ways. ${ }^{37}$

In Brown v. Hansen Publications, Inc. ${ }^{38}$ a music publisher gave preferential pricing to its wholly owned retail subsidiary. While the subsidi-

29. See Huddleston, supra note 18 , at 960 .

30. See, e.g., Brown v. Hansen Publications, Inc., 556 F.2d 969 (9th Cir. 1977); Reines Distrib., Inc. v. Admiral Corp., 241 F. Supp. 814 (S.D.N.Y. 1964); Baim \& Blank, Inc. v. Philco Corp., 148 F. Supp. 541 (E.D.N.Y. 1957).

31. 148 F. Supp. 541 (E.D.N.Y. 1957).

32. Id. at 543-44.

33. Id.

34. 241 F. Supp. 814 (S.D.N.Y. 1964).

35. Id. at 815 .

36. Id. (citing Western Fruit Growers Sales Co. v. FTC, 322 F.2d 67 (9th Cir. 1963), cert. denied, 376 U.S. 907 (1964), for a hist of factors to be considered in assessing dominion and control).

37. See, e.g., Scliaben v. Samuel Moore \& Co., 606 F.2d 831 (8th Cir. 1979); Parrish v. Cox, 586 F.2d 9 (6th Cir. 1978); Brown v. Hansen Publications, Inc., 556 F.2d 969 (9th Cir. 1977).

38. 556 F.2d 969 (9th Cir. 1977). 
ary had complete control over the pricing of the sheet music it sold, the parent and subsidiary were under unified ownership and shared officers and directors. The Ninth Circuit held that control over pricing pohicy alone was not determinative of whether the subsidiary qualified as a different purchaser and ruled that dominion and control was established by the common ownership and shared personnel. ${ }^{39}$ The retail subsidiary was therefore not a different purchaser, and the court held that no violation of the Act occurred. ${ }^{40}$

In Parrish v. Cox ${ }^{41}$ the plaintiff gas station owner claimed that the defendant sold gasoline and supplies to stations it owned at prices lower than those charged the plaintiff. ${ }^{42}$ The plaintiff contended that the defendant's subsidiary stations were able to make a profit by charging retail prices four to five cents per gallon below those that the plaintiff could afford to charge. ${ }^{43}$ The trial court held that the parent-subsidiary transfers were not sales under the Act unless the subsidiary was "operated independently of dominion and control of [the] defendant."44 Unlike the court in Brown, the Parrish court did not try to define the elements of dominion and control. ${ }^{45}$ There was no evidence, for exainple, of common corporate officers and directors. The court found, however, that the station subsidiaries were under the direct operating control of the defendant and that exchanges between the defendant and the stations were consignments rather than sales. ${ }^{46}$ The Sixth Circuit affirmed, finding the lower court opinion "clearly not erroneous."47

Other courts attempted to be more specific about what constituted dominion and control, as the court did in Brown. ${ }^{48}$ In Schaben v. Samuel Moore \& $\mathrm{Co}^{49}$ the Eighth Circuit reviewed a district court finding that product transfers from Samuel Moore to its subsidiary, Couplamatic, were not sales under the Act. The district court assessed Samuel Moore's dominion and control over Couplamatic by examining Samuel Moore's corporate structure and accounting practices. ${ }^{50}$ It found that Sainuel Moore treated its subsidiary as a division or profit center rather

39. Id. at 971-72.

40. Id. at 972.

41. 586 F.2d 9 (6th Cir. 1978).

42. Id. at $10-11$.

43. Id. at 11 n.3.

44. Id. at 12. The trial court also found that there was no lessening of competition between Parrish and the company-owned stations. Id. at 11.

45. The court did, however, cite in a footnote the factors that the district court found relevant. These included daily supervision of the company-owned stations, control over their business records, and control over retail prices. Id. at 12 n.7.

46. Id. at 12 .

47. Id.

48. Brown v. Hansen Publications, Inc., 556 F.2d 969 (9th Cir. 1977).

49. 606 F.2d 831 (8th Cir. 1979).

50. Id. at 833 . 
than as a separate corporation, making exchanges between them intracompany transfers instead of sales under the Act. ${ }^{51}$ The Eighth Circuit affirmed the judgment on appeal..$^{52}$

The dominion-and-control test represents a flexible approach to determining whether subsidiaries are different purchasers under the Robinson-Patman Act. As the cases discussed above show, the courts have looked to such factors as accounting practices, passage of title, shared personnel, and control over pricing practices to determine whether the subsidiary should be considered part of the parent firm. This flexibility led several federal circuits to adopt the test. Dominionand-control analysis has been partially replaced in recent years, however, by a wholly different approach.

\section{The Current Trend: Toward a Single-Entity Rule}

The Fifth Circuit's decision in Security Tire \& Rubber Co. v. Gates Rubber Co. ${ }^{53}$ signaled a sharp move away from the dominion-and-control test. The defendant rubber company was charged with violating the Act by selling goods to its tireinaking subsidiary on more favorable terms than to the plaintiff tiremaker. ${ }^{54}$ The court rejected the Danko holding that parent ownership of the subsidiary could not defeat the characterization of parent and subsidiary as vendor and purchaser. ${ }^{55}$ Yet the court also rejected the dominion-and-control test, adopting a per se rule instead: parent firms and wholly owned subsidiaries should always be treated as single entities under the Act. ${ }^{56}$ The court held that internal transactions are mere transfers, not sales, for Robinson-Patinan Act purposes. $^{57}$

At least two circuits that previously applied the dominion-and-control test have since opted to follow the single-entity rule of Security Tire $\&$ Rubber Co. The Sixth Circuit made the sharpest break in Russ' Kwik Car Wash v. Marathon Petroleum $C_{0}{ }^{58}$ The plaintiff was a gas station owner challenging defendant's preferential pricing for coinpany-owned retail subsidiaries. ${ }^{59}$ The court traced previous Sixth Circuit cases on point and found that the dominion-and-control standard prevailed..$^{60}$ Because the appeal was froin a summary judgment order, the court

\footnotetext{
51. Id.

52. Id. at 834 .

53. 598 F.2d 962 (5th Cir.), cert. denied, 444 U.S. 942 (1979).

54. Id. at $964-65$.

55. Id. at $965-66$.

56. Id. at 966 (also refusing "to exalt form over substance").

57. Id. at 965 .

58. 772 F.2d 214 (6th Cir. 1985).

59. Id. at 215 .

60. Id. at 219.
} 
decided not to review the factual evidence on dominion and control. ${ }^{61}$ Yet instead of remanding for findings of fact, it chose to decide directly whether the Security Tire \& Rubber Co. standard should be adopted. ${ }^{62}$

The court decided that any interference with parent-subsidiary pricing would also limit the parent firm's ability to confer other benefits on the subsidiary. ${ }^{63}$ Furthermore, the court found that consistency with Copperweld Corp. v. Independence Tube Corp. ${ }^{64}$ demanded that the parties be considered a single entity. ${ }^{65}$ The court therefore ruled that the Security Tire \& Rubber Co. rule should be adopted in the Sixth Circuit and that parent firms and wholly owned subsidiaries were per se single entities for Robinson-Patman Act purposes. ${ }^{66}$

Three years after Russ' Kwik Car Wash the Eighth Circuit discarded the dominion-and-control test it had apphed in Schaben and adopted the single-entity rule in City of Mt. Pleasant v. Associated Electrical Cooperative. ${ }^{67}$ The court ruled that a power coinpany could sell to its distribution subsidiary at prices lower than those it charged to the plaintiff city without violating the Act. ${ }^{68}$ The court argued that the defendant could have made the distribution cooperative an unincorporated division instead of a separately incorporated subsidiary. ${ }^{69}$ The plaintiff would then have had no grounds for coinplaint. ${ }^{70}$ The court therefore held that calling parent-subsidiary transactions "sales" under the Act "would . . . inake antitrust hability hinge on the happenstance of the enterprise's internal organization and manageinent practices, which in theinselves have no economic significance."71 The court also indicated that both consistency with Copperweld Corp. and the ability of a firm to enjoy "the fruits of vertical integration" required that the single-entity standard be adopted. ${ }^{72}$

61. Id. at 220 (stating that it is the district court's role to examine the record and determine the issue of control).

62. Id. (deciding that if the court of appeals cannot make the factual determination of dominion and control, it will have to face the question of whether to adopt the single-entity rule).

63. Id. at 220-21.

64. 467 U.S. 752 (1984); see supra note 6 (discussing why Copperweld Corp. is not necessarily dispositive in Robinson-Patınan Act cases).

65. Russ's Kwik Car Wash, 772 F.2d at 221 (using Copperweld Corp. court's holding that a parent and subsidiary cannot conspire to find that exchanges are transfers not sales).

66. Id.

67. 838 F.2d 268, 278-79 (8th Cir. 1988).

68. Id.

69. Id.

70. Id.; see also Snyder v. Howard Johnson's Motor Lodges, Inc., 412 F. Supp. 724, 730-31

(S.D. Ill. 1976) (holding that the Act does not apply to interdivisional transfers).

71. City of Mt. Pleasant, 838 F.2d at 279.

72. Id. 


\section{Policy Comparison and Analysis}

\section{The Dominion-and-Control Test}

Courts applying the dominion-and-control test viewed it as a way to safeguard the purposes of the Robinson-Patınan Act without depriving firms of the benefits of vertical integration and ownership. Because the test recognizes the potential inarket effects of parent-subsidiary pricing, it exempts transfers from scrutiny only if the subsidiary is truly integrated into the parent firm - that is, if the parent controls the subsidiary as well as owns it. As one proponent noted, "[u]nder this test a court would examine the economic reality underlying the parent-subsidiary relationship."73

The dominion-and-control test is a significant improvement over Danko, which held that subsidiaries were always different purchasers. ${ }^{74}$ Proponents of the test agree with proponents of the single-entity rule that it is senseless to apply the Act to subsidiaries, but not to divisions, solely on the grounds that subsidiaries are separately incorporated. Yet advocates of the dominion-and-control test believe that the single-entity rule goes too far in the other direction, ignoring the economic substance of parent-subsidiary relations. ${ }^{75}$

The effectiveness of the dominion-and-control test, however, can be questioned on several grounds. Under dominion-and-control doctrine, a court will punish separate incorporation if it finds that the subsidiary operates independently of the parent. One problem with this, as the court in City of Mt. Pleasant noted, is that the parent firm may respond by reorganizing subsidiaries as divisions of the parent. ${ }^{76}$ Such reorganization would thwart the statute's purpose. ${ }^{77}$ In addition it can be beneficial for the firm to separately incorporate subunits, either to take advantage of state corporate law $^{78}$ or to preserve the independent corporate culture of an acquired firm. Applying the Act to parent-subsidiary transactions imght encourage enterprises to adopt less efficient organiza-

73. Huddleston, supra note 18 , at 958.

74. Danko v. Shell Oil Co., 115 F. Supp. 886, 888 (E.D.N.Y. 1953) ("The fact that defendant itself may own and control such filling station would not destroy the relationship of vendor and purchaser.").

75. Huddleston, supra note 18 , at 958.

76. City of Mt. Pleasant v. Associated Elec. Coop., 838 F.2d 268, 278 (8th Cir. 1988) (stating that defendant could simply have restructured subsidiaries as unincorporated divisions).

77. Id. at 279.

78. This factor may be particularly important in the context of the Robinson-Patman Act. The Act applies only when the defendant is engaged in interstate commerce and one of the disputed sales is also in interstate commerce. Thus, suits based on the Robinson-Patman Act often concern sales from parent firms to out-of-state subsidiaries. If a firm can escape Robinson-Patman Act hability by making the subsidiary a division withm the parent corporation, there seems to be no reason for not letting the firm benefit from separate incorporation when it finds it desirable to do so. 
tional structures. ${ }^{79}$ The plaintiff does not benefit from this reorganization, and the parent and subsidiary also lose. ${ }^{80}$

Moreover, even if the Act prevented a parent firm from selling goods more cheaply to its subsidiary than to outsiders, the competitor might not benefit. The parent might subsidize the subsidiary through means other than price: it can buy equipment for the subsidiary, make low-imterest loans, donate services, or otherwise help it to be more competitive. Because such actions fall outside the Robmson-Patman Act ${ }^{81}$ and cannot be challenged under the Sherman Act after Copperweld Corp., ${ }^{82}$ the expected benefits to competitors from prohibiting differential imtraenterprise pricing fail to materialize. Ultimately, barring differential pricing between parent and subsidiary does not necessarily further the purposes of the Act-it might only force the parent to find other ways to aid the subsidiary, thus offering no long-term benefits to competitors and no spur to competition generally. Furthermore, consumers will lose because they will have to pay more for the subsidiary's products.

Advocates of the dominion-and-control test argue that the test distimguishes cases in which separate imcorporation serves legitimate purposes from cases in which it does not. This is questionable given that the test rehes on very broad and crude measures. As discussed above, different courts weigh different factors in different ways, and nltimately the test rehes on the courts to know control when they see it. As will be discussed in Part III, while the test purports to heed the econorimc reality of parent-subsidiary relations, it ignores the microeconomic realities of intraenterprise pricing. ${ }^{83}$

79. There might be cases in which the organizational efficiency resulting from separate incorporation is so substantial that the firm will maintain the subsidiary structure despite the Act's constraints. As a result, the plaintiff alleging a violation of the Robinson-Patman Act benefits by avoiding the price squeeze, and the efficiency loss from changing the firm's structure is averted. As will be argued infra, Part IV, the change in pricing policy required under the Act, however, will itself cause problems. Furthermore, it is questionable whether the dominion-and-control test, or any judicial standard, can distimguish cases when separate incorporation will be maintained from those when it will not.

80. One might argue the converse: the simgle-entity rule will encourage firms to purchase downstream firms (firms playing roles further along in a production process-for example, a tiremaker is "downstream" from a rubber producer) to make them wholly owned subsidiaries and to price discrimimate to gain a competitive advantage in the downstream market. Such an argument is highly suspect. First, there are substantial costs to ownership, and there is no evidence that those costs would be offset by the alleged competitive gains. Second, firms can already escape the Act by making downstream firms internal divisions of the aequiring firm. Therefore, it is unclear that a single-entity rule would add a "perverse" incentive not already present.

81. See HovenKAMP, supra note 2, at 348-49 (discussing discrimination in the provision of services on a sale covered by the Act). The Act, however, does not apply to services unrelated to a particular sale: it applies to credit terms on the given sale but not to other benefits the parent can give the subsidiary. Id.

82. Copperweld Corp. v. Independence Tube Corp., 467 U.S. 752, $771-77$ (1984) (holding that $\S 1$ of the Sherman Act does not apply to parents conspiring with their subsidiaries).

83. See infra notes $92-119$ and accompanying text. 


\section{The Single-Entity Rule}

The single-entity rule has two major advantages over the dominionand-control test. First, it ensures that courts will not interfere with intraenterprise pricing relations. When a firm assumes full ownership of a subsidiary it acquires risk along with the assets. To best manage the risk associated with ownership, substantial managerial discretion is needed. By eliminating the different-purchaser designation from subsidiaries, the single-entity rule frees inanagers from legal constraints when arranging parent-subsidiary transactions. They can therefore inake pricing decisions that maximize the returns resulting from subsidiary ownership.

The second major advantage of the simgle-entity rule is administrability. The rule is easy for courts to apply and does not require elaborate and time-consuming evidentiary showings: the plaintiff loses as soon as the court finds that the parent firm owns the subsidiary that is allegedly benefiting from the differential pricing. In coinparison, the doininion-and-control test can require evidence of accounting systeins, personnel records, decisionmaking processes, and other factors. Moreover, after this evidentiary burden is met, the court still must decide how to weigh the different factors to determine whether dominion and control exists.

In addition to these advantages, applying the simgle-entity rule avoids making hability contingent on the legal form of the enterprise. In exempting internal transactions from the $\mathrm{Act}^{84}$ Congress recognized limitations or trade-offs with respect to its distributional goals. ${ }^{85}$ To the extent that parent-subsidiary sales are functionally identical to sales between divisions of the saine corporation, placing thein outside of the Act's reach is in accord with the imphicit trade-offs einbodied in the Act.

Critics, however, can argne that despite the limitation inplicit in Congress' decision not to extend the Act to interdivisional transfers, the potential for price squeezes under the single-entity rule leads to outcomes contrary to the Act's goals. ${ }^{86}$ They might contend that although the single entity rule purports to adopt economic substance over legal form, apphication of the rule depends entirely on corporate ownership. ${ }^{87}$

84. Huddleston, supra note 18 , at $966 \mathrm{nn} .59-60$ (noting that during the House hearings the drafters of the Act stated that although a parent selling to its subsidiary at a lower cost in order to "squeeze" coinpetitors was not desirable, the practice was not covered by the Act).

85. See supra text accompanying notes 19-22.

86. Huddleston, supra note 18, at 968 (acknowledging that the same harm comes from interdivisional transfers that are exempt from Robinson-Patman Act regulation). For a morc detailed discussion of the price-squeeze phenomenon, see supra text accompanying notes 16-17.

87. See Huddleston, supra note 18, at 971 (criticizing the Security Tire \& Rubber Co. court for looking solely at corporate ownership and ignoring the econounics of the parent-subsidiary relationship). 
Because corporate ownership itself is not the only component of economic substance, a better analysis would examine more closely how the parent and subsidiary are organized with respect to each other. ${ }^{88}$ Thus, critics can argue that the trade-off between distributive goals and effciency suggested in the legislative history is better accomphished by a different rule: one that applies to parent-subsidiary sales when the net effect furthers the Act's goals but does not apply when the costs are too high or when the transaction is functionally equivalent to an interdivisional sale. The dominion-and-control test purportedly accomphishes this.

\section{Summary}

A review of both the statutory language of the Robinson-Patman Act and the case law addressing parent-subsidiary sales offers no clear answer as to whether wholly owned subsidiaries qualify as different purchasers under the Act. Some circuits, mcluding the Ninth, apply the dominion-and-control test. ${ }^{89}$ Others, like the Fifth, Sixth, and Eighth Circuits, now apply a per se single-entity rule. ${ }^{90}$ Despite the trend toward the smgle-entity rule, uniformity among the circuits is not clearly imminent. Federal courts continue to wrestle with the issue: Judge Motley of the Southern District of New York refused to dismiss a claim in 1987 because of "the unsettled status of the law re parent and purchaser subsidiary." 91 The Supreme Court has not yet decided the issue.

Policy analysis reveals problems with both doctrines. The dominion-and-control test suffers from two. First, parent firms can work around enforcement by reorganizing subsidiaries as divisions or by conferring equivalent benefits on subsidiaries through nonprice means. Second, the test is vague, and the factors considered do not necessarily afford an accurate reading of dominion and control. The single-entity

88. See id. (arguing that the dominion-and-control test is superior because it examines the actual relationship between the entities).

89. See, e.g., Brown v. Hansen Publications, Inc., 556 F.2d 969 (9th Cir. 1977); Reines Distrib., Inc. v. Admiral Corp., 241 F. Supp. 814 (S.D.N.Y. 1964).

90. City of Mt. Pleasant v. Associated Elec. Coop., 838 F.2d 268 (8tlı Cir. 1988); Russ' Kwik Car Wash v. Marathon Petroleum Co., 772 F.2d 214 (6th Cir. 1985); Security Tire \& Rubber Co. v. Gates Rubber Co., 598 F.2d 962 (5th Cir.), cert. denied, 444 U.S. 942 (1979).

91. Supra USA Inc. v. Samsung Elec. Co., 1987-2 Trade Cas. (CCH) \f 67,760, at 59,063 (S.D.N.Y. 1987) (denying defendant's motion to certify to the Court of Appeals the question of whether the Second Circuit should adopt the Security Tire \& Rubber Co. test). Judge Motley argued that the law of the other circuits did not apply and cited Judge Kennedy's dissent in Russ' Kwik Car Wash with approval. Id. at 59,068 .

The dominion-and-control test still lias support among judges and coinmentators. See, e.g., Huddleston, supra note 18 (arguing that courts should use the dominion-and-control test because it "looks to economic substance rather than legal form," id. at 969); Russ' Kwik Car Wash, 772 F.2d at 223 (Kennedy, J., dissenting) (distinguishing Copperweld Corp. v. Independence Tube Corp. and arguing that the dominion-and-control test is not mconsistent with the result in that case). 
rule, however, can allow price squeezes and other predatory conduct to go unchecked. It can also defeat the Act's purpose of protecting sinall competitors, although the statute does not specify how far that goal is to be pursued.

The following Part imtroduces a new analysis that should better inform the debate. It discusses the managerial purposes served by transfer pricing and argues that interference with these purposes through application of the Robinson-Patman Act can lead to serious econoinic costs offset only by speculative and doubtful benefits.

\section{III}

\section{The Organizational Role of Internal Pricing}

In deciding whether the Act shonld apply to parent-subsidiary transactions, the inanagerial functions served by internal pricing decisions must be considered. For the most part judges and commentators have iguored the organizational purposes of internal pricing. In some cases courts state, without analysis, either that internal pricing decisions should be left to management discretion or that they have no economic significance.92 In other cases courts use "efficiency," without elaboration, as a justification for allowing parent-subsidiary behavior to proceed unregulated. ${ }^{93}$

This Part argues that internal pricing serves several important functions in firm management, each of which often creates valid reasons to price differentially to subsidiaries quite apart from any anticompetitive aims of the parent firm. Further, it is difficult for courts to distinguish meaningfully between justified and unjustified managerial pricing decisions. ${ }^{94}$ This argument addresses the implicit trade-off in the Act and attempts to give content to the analysis of the costs and benefits of applying the Act to parent-subsidiary sales.

\section{A. The Managerial Goals of Intraenterprise Pricing}

Research on intraenterprise transfers has focused on three criteria of effective transfer pricing: efficiency, mointoring, and fairness. ${ }^{95}$ None of

92. See, e.g., City of Mt. Pleasant, 838 F.2d at 279 (stating internal pricing is part of managerial decisionmaking that in itself has no economic significance).

93. Cf. Copperweld Corp. v. Independence Tube Corp., 467 U.S. 752, 773 (1984) (emphasizing that enterprises should be frec to pursue the economic efficiencies of a parent-subsidiary relationship under the Sherman Act).

94. The dominion-and-control test is clearly such an effort to distinguish legitimatc from invalid differential pricing. As discussed infra text accompanying notes 95-117, the results of such inquiries are hikely to be arbitrary and can do more harm than good. See supra text accompanying notes 73-83.

95. See ECCLES, supra note 3, at 10-11 (discussing efficiency and fairness as criteria for evaluating the effectiveness of transfer-pricing strategies). 
these goals in itself is sufficient to explain the transfer-pricing policies observed in practice. All three considerations shape inanagerial policy. Examination of the criteria demonstrates that each can lead to a variety of transfer-pricing policies and inake it sensible for the firm to price parent-subsidiary "sales" at levels that differ from those charged to outside purchasers.

\section{Economic Efficiency as a Transfer-Pricing Goal}

One criticisin of the single-entity test is that a firm can give its subsidiary a cost advantage that would enable it to squeeze competition from the market in which it operates. ${ }^{96}$ Yet neoclassical economic analysis reveals that the inost efficient transfer price for the enterprise itself can differ from the inarket price. Theoretical research has shown that in an environment of costless and perfect information, the firm operates most efficiently by transfer pricing at the inarket rate only when there is a perfectly competitive inarket for the product being transferred. ${ }^{97}$

When tliere is a perfectly competitive market for a product, producers sell the product at marginal cost; if the market is not perfectly coinpetitive, producers can charge a price above their marginal costs and earn an economic profit. Professor Hirshleifer has proven that in the latter case it is inefficient for internal transfers to be priced at the market rate. ${ }^{98}$ Rather, they should be priced at inarginal cost, below the market rate. ${ }^{99}$

Because very few imdustrial coinponents are exchanged in a purely coinpetitive market, ${ }^{100}$ their market prices are usually greater than marginal cost. Therefore, pure economic reasoning argues that, for a firm to be efficient, intrafirm coinponent sales must generally occur at prices below the market price. Robinson-Patman Act regulation of such differential pricmg requires firms either to give up the profits they can earn through market sales or to sacrifice the most efficient internal pricing scheine. As a inatter of sound economic pohicy, firms should not be forced to make such a choice. ${ }^{101}$

96. For a discussion of the price squeeze, see supra text accompanying notes 16-17.

97. Jack Hirshleifer, On the Economics of Transfer Pricing, 29 J. Bus. 172, 172 (1956.

98. See id. at 178-79.

99. See id. at 179.

100. ECCLES, supra note 3, at 21 .

101. One might argue that the Act is good policy if it forces firms to give up supracompetitive profits. This result is only problematic when the firm takes efficiency losses to preserve its supranormal profits, as when it raises its internal price mefficiently to preserve its market profits. Yet even where the firm maintains an efficient internal-pricing policy, forcing it to cliarge the same price externally can be bad policy. Once the firm loses its ligh profits on the outside market, it miglit refuse to sell the good outside of the firm at all. Reduced mcentive to participate in the outside market, both for imcumbents and potential entrants, only liarms the market for the particular 


\section{Intraenterprise Pricing and Performance Monitoring}

Critics of the pure economic analysis of transfer pricing argue that marginal cost is mipossible to measure and that the informational assumptions of the analysis are unrealistic. ${ }^{102}$ They also argue that pure economic analysis ignores managerial goals other than efficiency that play a role in setting intraenterprise prices. ${ }^{103}$

Momitoring the performance of subsidiaries through accounting systems is one such goal. Firms often transfer resources between divisions or between the parent firm and a subsidiary. Accounting systems measure the inputs and outputs of each division. For this reason, resource transfers within the enterprise are priced, with divisions paying and being paid for what they buy and sell internally. In this way headquarters can keep a "book" on each division or subsidiary to measure and reward perfornance.

When an organization transfers goods and services between its subunits, the buyer makes a "transfer payment" that appears in the accounting profits of the selling unit. Firm inanagers and accountants attempt to find transfer prices that allow for accurate divisional perfornance evaluation. ${ }^{104}$ Two basic categories of transfer prices are used in practice: administered prices, which are generally cost based, and negotiated prices, which are usually market based. ${ }^{105}$

A full discussion of the relative inerits of different accounting programs is beyond the scope of this Comment. A review of the accounting hiterature, however, shows that when transfer prices are chosen for monitoring purposes and for measuring divisional perfornance, there is no reason to behieve that they will equal the inarket price for the same good. Central managennent might find that in some cases it receives more accu-

good. For an entertaining story illustrating these kinds of effects, see generally William F. Baxter, $A$ Parable, 23 STAN. L. REV. 973 (1971).

102. See, e.g., ECCLES, supra note 3, at 22-25 (discussing difficulties in calculating marginal cost and criticizing assumptions of pure economic-theory solutions to transfer-pricing problems); Robert G. Eccles \& Harrison C. White, Price and Authority in Inter-Profit Center Transactions, 94 AM. J. Soc. S17, S21, S48 (Supp. 1988) (positing that the assumptions used in economic models regarding marginal-cost derivation and other transfer-pricing methods do not accurately reflect inethods used in practicc).

103. For an overview of such managerial goals that are purportedly ignored by pure economic analysis, see ECCLES, supra note 3, at 22-25.

104. David Solomons, Divisional Performance: Measurement and Control 166 (1965).

105. Eccles, supra note 3, at 40; Price Waterhouse, Transfer Pricing in American INDUSTRY (1984).

To be precise, the terms "administered" and "negotiated" refer to the processes managers use to set transfer prices and not to the prices themselves. On the other hand, "market-based" and "costbased" refer to types of prices. The terms are often used interchangeably because in practice administered prices are usually based on cost factors while the benchınarks for negotiated prices are narket prices. 
rate performance information from cost-based rather than market-based pricing entries. In other cases it might not want to let two subunits negotiate prices if their bargaining power is unequal because subsidiary profits will reflect bargaining skill as much as true economic performance.

\section{Managerial Fairness}

Because the methods of determining and accounting for transfer prices affect divisional performance ratings, inanagers are sensitive to the sizes of the transfer payments they make and receive. They are likely to be particularly upset if they think the inanager of another uint of the company is getting a better deal than they are. ${ }^{106}$ Thus, Professor Richard Vancil found that managers were concerned with fairness when setting transfer prices even if it compromised the accompanyimg goals of efficiency or monitoring. ${ }^{107}$ Other commentators have argued that social considerations define the intraenterprise price: ${ }^{108}$ "the valuation of an inter-profit center exchange . . . both defines, and is defined by, the social relationship represented in the exchange."109 A subsidiary manager could find a transfer price unfairly harmful to her profits, resulting in conflict and lower productivity. ${ }^{110}$

An example of a transfer-pricing pohicy with fairness in mind is the equal-profit-margin (EPM) approach. ${ }^{111}$ Under EPM the firm sets a price that equalizes the final profit margins of the parent and subsidiary (or the two divisions) on the transferred good. ${ }^{112}$ Such a pohicy affords numerous benefits. Two accounting scholars who studied the EPM approach at a company they called $\mathrm{XYZ}^{113}$ reported the following:

106. See James N. Baron, The Employment Relation as a Social Relation, 2 J. JAPANESE \& INT'L ECONOMIES 492, 499-504 (1988) (discussing peer groups and the role of social coinparison in Inaking fairness judgments, particularly horizontal comparisons between persons similarly situated in an organization).

107. See Richard F. VANCIL, Decentralization: MANAgerial Ambiguity by Design 113 (1978) (noting that managers deemed basing transfer prices on volume of sales that corporate sales force produced for each profit center a fair method of transfer pricing). In this study Vancil surveyed over $\mathbf{2 0 0}$ firms, colleeting detailed information on their intraenterprise transactions.

108. See generally Eccles \& White, supra note 102, at S17 (noting the role of certain social mechanisms in setting transfer-pricing policies).

109. Id. at S19.

110. See ECCLES, supra note 3, at $45,270-71$.

111. See generally Nahum Melumad \& Stefan Reichelstein, Transfer Pricing at XYZ: The Equal-Profit-Margin Approach (n.d.) (unpublished preliminary teaching note, on file with author) (explaining the equal-profit-margin approach for transfer pricing).

112. See id. at 2-3 (providing an example of EPM in practice). "Final profit margins" are ratios of operating profit to net revenues. Id. at 1.

113. Id. at 4. The authors were obliged not to reveal the name of the company where they conducted their research. This is a common requirement in business research. See, e.g., ROBERT G. ECCLES, supra note 3, at xvi (noting that author used fictional names for the compamies and managers participating in his study). 
We have discussed the matter with $X Y Z$ officials who argued that the main rationale behind the EPM transfer pricing scheme is fairness. They felt that the "more equal" the divisional profits are, the higher the level of acceptance of the transfer pricing scheme by divisional managers within the counpany, with the presuined consequence of better cooperation among those managers. ${ }^{114}$

Settimg transfer prices that are fair, therefore, is important for managing a firm. ${ }^{115}$ If the subunit to which the good or service is sold is a separately incorporated subsidiary, there can be good reason for the parent firm to choose a transfer price like EPM. The EPM price paid by the subsidiary is by definition lower than the hist price charged to an outside buyer. ${ }^{116}$ Therefore, differential pricing should not necessarily be interpreted as part of an anticoinpetitive strategy but rather can be the result of sound inanagement.

\section{B. Summary and Policy Implications}

Accounting, management science, and economic theory each have different views of the purposes and constraints of transfer pricing. Yet all agree that whether the goal is effectively to ineasure divisional performance, to keep inanagers happy and cooperative, or to inaximize profits, there are sound reasons to charge wholly owned subumits different prices froin those charged to inarket customers. These justifications are based on effective and efficient inanagerial and organizational considerations and not on anticompetitive strategies; if courts are to apply the Robinson-Patman Act to parent-subsidiary transactions, they inust have a test that can distinginsh these types of considerations froin anticompetitive ones.

The dominion-and-control approach is designed to account for such inanagerial considerations. The test tries to distimguish cases in which judicial deference to inanagers' pricing decisions is warranted froin those in which it is not. One flaw with the dominion-and-control test, however, is that it relies on broad indicators sucli as accounting systems and overlapping directorates. ${ }^{117}$ The test does not require courts explicitly to account for inonitoring and fairness considerations. Thus, to the extent that broad factors fail to capture important managerial considerations,

114. Melumad \& Reichelstein, supra note 111, at 4.

115. One reason for a "fair" equal-division rule is that it avoids a bargaining breakdown over the distribution of surplus resulting from the internal transaction. Thus "fair" pricing enhances overall efficiency by reducing bargaining costs even though the transactions are not theniselves efficiently priced.

116. The intrafirm price is lower because the price paid by outside purchasers will have the joint (parent and subsidiary) profit inargius built into it whereas the subsidiary splits the margin with the parent firm.

117. See supra text accompanying notes 30-52. 
the dominion-and-control test can interfere with efficient and reasonable firm organization.

Critics of the single-entity test, on the other hand, can argue that although differential pricing may be justified in inany cases, removing all parent-subsidiary transfers froin Robinson-Patman Act scrutiny is unwarranted. For example, they can argue that it is unlikely that a separately incorporated subsidiary with completely different persomiel, management structure, and accounting systenis will be subject to the fairness considerations of the parent company. Furthermore, if the accounting systeins were separate, the parent coinpany could not justify charging the subsidiary a differential price by claiming to have legitimate performance-1neasurentent considerations. Critics of the single-entity test can argue, therefore, that the dominion-and-control test provides an adequate safeguard against truly perverse Robinson-Patman Act regulation while also furthering the Act's goals. The next Part will challenge this assertion by more carefully analyzing how control can be exercised in parent-subsidiary relationships.

\section{IV \\ Intraenterprise-Pricing Policy and Transaction Costs}

The dominion-and-control test is based on the premise that if a parent firm wants to control a subsidiary, it does so through broad operational and managerial ineasures-for example, by sharing top executives, using a unified accounting system, or keeping title to goods. Such a test for control will be ineffective, however, if parent firms permit their subsidiaries to function independently in most cases but occasionally require a more tightly administered and coordinated relationship for the purposes of individual transactions. In that case, it would be possible for the parent to control the particular transaction even though the parent and subsidiary have none of the nornal characteristics examined under the dominion-and-control test.

There is coinpelling evidence that transfer-pricing decisions are based on transaction-level factors. Surveys gathering transfer-pricing data almost uniformly report that firms use multiple policies ${ }^{118}$ and, even inore to the point, that they often use multiple policies in reaching transfer-pricing decisions for transactions between the same two subunits. ${ }^{119}$ The latter finding implies that although, for example, the accounting systenis and inanagement structure between the parent and its subsidiary

118. See Roger Y.W. Tang, Transfer Pricing Practices In the United States and JAPAN ch. 2 (1979) (discussing a variety of surveys of transfer pricing); PRICE WATERHouse, supra note 105 , at 4, 8; ECCLES, supra note 3, at 40.

119. See, e.g., ECCLES, supra note 3, at 56-57. 
are fixed, the transfer-pricing policies vary among transactions. This mdicates that inanagers make pricing decisions based at least partially on factors arising out of the specific transaction being priced. Tests to determine dominion and control based on firm-level factors iniss this microanalytic detail and miglit inhibit firms froin organizing transactions as tliey see best.

This Part uses transaction-cost economics to examine how transferpricing policy can be determined by the cliaracteristics of individual transactions. It will argue that control by the parent firm is often appropriately exercised at the level of mdividual transactions and that there are systematic alignments between the type of transaction and the transferpricmg pohicy used. This Part of the Comment presents original empirical research to support the arguinent. It will further argue that judging the legality of differential pricing based on transaction-level factors is extremely difficult and beyond the competence of both courts and public agencies. This Part begins by presentimg some background for transaction-cost economics.

\section{A. Transaction-Cost Economics}

Transaction-cost economics (TCE) has roots in older traditions of institutional economics. The work of John Commons and Ronald Coase was especially important for the development of TCE. Cominons was the first to make the transaction the fundamental unit of analysis in the study of contracts and economic exchange. ${ }^{120}$ Coase was the first to define tlie boundary between firms and markets as being determined by the relative costs of mediating transactions. ${ }^{121}$

Modern transaction-cost economics has built on the older work to develop an operational theory of economic organization. ${ }^{122}$ In brief, TCE argues that transactions differ in their complexity and costliness and that the structures used to govern transactions-for example, markets, firms, and contracts-differ im their economizing advantages and incentive provisions. The goal of TCE is to aligu transactions with governance structures in a cost-economizing manner.

120. See generally 1 John R. Commons, Institutional Economics: Its Place 1N Polmtical Economy 55-93 (U. Wis. Press 1959) (1934) (explaining why Commons chose the transaction as the fundamental unit of economic activity over the units-commodities and individuals-used in classical economic theory).

121. See generally R.H. Coase, The Nature of the Firm, 4 EcoNomicA 386 (n.s. 1937) (explaining Coase's justification for distinguishing the firm on the basis of transaction costs).

122. The pathbreaking works in this field are OLIVER E. WILliamson, ThE Economic INSTITUTIONS OF CAPITALISM: FIRMS, MARKETS, RELATIONAL CONTRACTING (1985) [hereinafter ECONOMic INSTITUTIONS], Benjamm Klein et al., Vertical Integration, Appropriable Rents, and the Competitive Contracting Process, 21 J.L. \& ECON. 297, 298 (1978), and Oliver E. Williamson, MARKETS AND HIERARCHIES: ANALYSIS AND ANTTTRUST IMPLICATIONS: A STUDY IN THE ECONOMICS OF INTERNAL ORGANIZATION (1975). 
For example, when large sunk costs are required to support exchange, safeguards to monitor the behavior of the parties and to facilitate adaptation to changed circumstances are needed because the investments will be lost if the transaction breaks down. ${ }^{123}$ TCE predicts that those transactions will be more easily mediated within firms, where the trading parties are under unified ownership. The theory predicts that unified ownership, or integration, will reduce opportunistic behavior by the trading parties and allow central management to mandate adaptation to changed circumstances. ${ }^{124}$

Standardized, recurring transactions of a more classical kind require hittle specialized investment and benefit more from high-powered performance imcentives than froin safeguards. In such cases TCE predicts that market forces will mediate behavior more efficiently than will unified ownership. ${ }^{125}$ This is because markets provide powerful profit incentives (but not hierarchical authority to safeguard transactions).

Two behavioral assumptions underhe TCE. First, economic actors are opportunistic. ${ }^{126}$ They will extract gains where possible, even if doing so violates the letter or spirit of the exchange agreement and takes advantage of the other party. ${ }^{127}$ Second, economic actors are constrained by bounded rationality. ${ }^{128}$ Limitations on human economic rationality arise from finite cognitive capacity and inability to predict the future, which in turn preclude contracting for all future contnigencies. ${ }^{129}$ Contracts are therefore unavoidably incomplete, creating the need for mechanisms that allow adaptation to change in complex transactions.

The premise here is that the principles informing the choice of a structure for mediating exchange do not disappear when a transaction is internalized. Instead they continue to operate inside the firm. The firm might adopt less integrated or more integrated structures even while having complete ownership of the entities. For example, one often conceives of the divisionalized firm (the $\mathbf{M}$-form enterprise) as having market-like properties. Organizing divisions along market lines reinforces managerial imcentives. The downside is that decentralization frustrates central

123. See ECONOMIC INSTITUTIONS, supra note 122, at 52-56 (describing inethods to safeguard special-purpose investments).

124. See id. at 78.

125. See id. at 73-74 (describing markets as particularly well suited for governing recurring transactions).

126. See id. at $48-49$.

127. Of course, not all economic actors are opportunistic; unany will forgo opportunistic gains and behave "honorably." If, however, there is soine probability that an economic actor is opportunistic, the other trading party will be wary.

128. See EcONOMic InSTITUTIONS, supra note 122, at 45.

129. This assumption comes from the work of Professor Herbert Simon, who described actors as "intendedly rational, but only limitedly so." Herbert A. SimON, ADMINISTRATIVE Behavior at xxiv (2d ed. 1957), quoted in ECONOMIC INSTITUTIONS, supra note 122, at 45. 
management's control and coordination of particular transactions. Mform firms, however, do not try to indiscriminately imitate markets. They use markets to provide imcentives and discipline managers. Similarly, they use administrative authority to coordinate exchange, mandate investment, or pursue other goals not necessarily in the interests of individual divisions or subsidiaries. Therefore, enterprises might organize transactions in ways that differ from the genuine M-form structure, ${ }^{130}$ using instead a "corrupted" M-form structure that gives subunits less autonomy and profit responsibility in soine circuinstances. ${ }^{131}$

Intraenterprise pricing policies are miportant managerial tools for organizing transactions. Administered (usually cost-based) and negotiated (usually market-based) transfer-pricing policies are alternative mechanisins for mediating parent-subsidiary transactions. The next Part imvestigates whether transfer-pricing pohcies are systennatically related to specific characteristics of their target transactions and analyzes the imphcations of such alignments for Robinson-Patman Act scrutiny of parentsubsidiary sales.

The analysis requires three steps. The first is to describe intraenterprise transactions im terms of the characteristics that raise transaction costs. The second is to compare the governance properties of different transfer-pricing policies. The third is to set out the alignments that should be made, and observed, in practice.

\section{B. Variables Affecting the Cost of Intraenterprise Transactions}

The theoretical and empirical TCE literature identifies several factors that contribute to the cost and complexity of transactions. ${ }^{132}$ While the specific form of these factors differs with the transactional context, the essential nature of the factors remanis the same. This Part briefly explores the most significant transaction-cost variables.

\section{Asset Specificity}

The most important factor in raising the costs of exchange is asset specificity ${ }^{133}$-fixed investment that is not recoverable if the transaction fails. Asset specificity takes many forms, including physical capital, human skills, and research and development. Asset specificity raises

130. See Bengt Holmstrom \& Jean Tirole, Transfer Pricing and Organizational Form 1, 2-3 (June 1991) (unpublished draft, on file with author) (firms can employ the genuine M-form, corrupted $\mathrm{M}$-form, or command-form structure).

131. See id. at 3.

132. See, e.g. EсоNomic INstitutions, supra note 122, at 68-84 (discussing governance of contractual relations). For a survey of empirical economic literature concerning TCE, see also Howard A. Shelanski, Empirical Research in Transaction Cost Economics: A Survey and Assessment (Dec. 1991) (unpublislied manuscript, on file with author).

133. See Benjamin Klein et al., supra note 122, at 298. 
transaction costs and increases the need for inore coordinated, less arm's length, mediation. Several einpirical studies have shown that as asset specificity increases, transactions are more likely to be vertically integrated than carried out on the inarket. ${ }^{134}$ When specific mvestment is at stake in parent-subsidiary exchanges, therefore, the likelihood increases that transactions will be inediated through mechanisins that are not at arm's length.

Unusual quality specifications, design coinplexity, and research-anddevelopinent requirements also expose transactions to hazards that might lead to contractual breakdown and economic loss by one or both parties. These losses can be mitigated through vertical integration. Professors Monteverde and Teece have shown einpirically that "[t]he greater is the ... engineering effort associated with the development of any given autoinobile coinponent, ... the greater is the likelihood of vertical integration of production for that coinponent."135 Another study also found a significant relationship between the design coinplexity of the coinponent being transferred and integrated modes of exchange. ${ }^{136}$

When the parties are integrated in a single firm, incentives to behave opportunistically go down and central inanagement can exercise authority over exchange. ${ }^{137}$ Management can adopt hierarchical, or coordinated, mediation to ensure that transactions are completed. This results in a inechanism for adapting to unforeseen contingencies that is less costly in terms of bargaining, momitoring, and arbitration than if the transaction were mediated through inarket contracts.

\section{Uncertainty}

Uncertainty over future contingencies-such as changes in technology and inarket conditions-becornes a concern when continuity in the exchange relation is valuable, as when specific investinents support the exchange. ${ }^{138}$ As uncertainty over future contimgencies increases so does the probability that the exchange will break down after the parties con-

134. See, e.g., Jean-Francois Hennart, Upstream Vertical Integration in the Aluminum and Tin Industries: A Comparative Study of the Choice between Market \& Intrafirm Coordination, 9 J. EcoN. BEHAV. \& ORG. 281, 284-87 (1988) (finding a positive relationship between vertical integration and degree of high capital intensity in bauxite industry); Scott E. Masten, The Organization of Production: Evidence from the Aerospace Industry, 27 J.L. \& EcoN. 403, 412 (1984) (finding that speeific investment in component production signifieantly increased the likelihood of internal Inanufacture); Kirk Monteverde \& David J. Teece, Appropriable Rents and Quasi-Vertical Integration, 25 J.L. \& ECON. 321, 324-27 (1982) (showing a relationship between specialized nature of asset and hikelihood of vertical ownership).

135. Kirk Monteverde \& David J. Teece, Supplier Switching Costs and Vertical Integration in the Automobile Industry, 13 BELL J. ECON. 206, 207 (1982).

136. See Masten, supra note 134 , at 417.

137. See ECONOMIC INSTITUTIONS, supra note 122, at 78.

138. Id. at $56,79-80$. 
tract. Trading parties will therefore seek adaptive mechanisms to safeguard the transaction. To the extent that coordination between the parties is costly, uncertainty raises transaction costs.

A second kind of uncertainty is a consequence of asymmetric mformation. If one party has superior information about the transaction, it might gain by misrepresenting or withholding relevant data. Where asymmetric information is likely, the party making specific investinents risks exploitation by a party with superior information. The exposed party will therefore deinand safeguards and mointoring mechanisins to protect itself, raising the costs of mediating exchange. ${ }^{139}$

The role of uncertainty in pushing parties toward more integrated transactions is einpirically supported. Multi-industry studies, for exan1ple, have found that uncertainty over future events in an industry increases the likelihood of vertical integration, particularly when one of the parties has made relationship-specific imvestments. ${ }^{140}$

\section{Frequency}

As exchange betwecn two parties involves more frequent transactions, the value of the exchange relation increases. ${ }^{141}$ The value enhancement from continuity arises from the detailed knowledge that parties gain about each other's requirements and ways of doing business. Because parent firms often purchase or estabhsh subsidiaries to be part of an ongoing production process, frequency considerations alinost always accompany intraenterprise transactions. Where exchange is frequent, parties can find it cost-effective to employ coordinating mechanisins that preserve their relationship when probleins arise. Such mechanisins incur higher transaction costs than those encountered for exchanges conducted purely at arm's length. ${ }^{142}$

\section{Governance Properties of Transfer-Pricing Policies}

The discussion above argued that certain variables increase the need for coordinated and hierarchical mediation of exchange. The empirical studies cited compared internal procurement with market procurement. Yet the variables discussed can also affect transactions occurring between commonly owned parties, such as intraenterprise sales. Parent firms

139. For a general discussion of the economics of asymmetric information, see DAVID M. KREPS, A COURSE IN Microeconomic THEORY chs. 16-18 (1990).

140. David T. Levy, The Transactions Cost Approach to Vertical Integration: An Empirical Examination, 67 REV. ECON. \& STAT. 438, 443 (1985) (finding correlation between uncertainty and vertical integration in manufacturing firms). Many other studies support this finding. See generally Shelanski, supra note 132, at 4-16 (surveying and assessing einpirical research in transaction-cost economics froin 1975 to present).

141. See Economic Institutions, supra note 122 , at $60-61$.

142. Id. 
might want to structure some of their exchanges with subsidiaries as market-like transactions, while making others coordinated and integrated. One way that managers make parent-subsidiary exchange inore or less at arm's length is through the pricing mechanisms used for intrafirm transfers.

Intraenterprise pricing mechanisms fall into two broad categories: administered prices determined by headquarters and prices negotiated between corporate entities independently of headquarters. ${ }^{143}$ The former are generally cost based and the latter are generally market based. Firms rely on different pricing policies depending on the type of transaction at stake. One policy is superior when transactions require coordination and adaptation, while another is preferred when the market-like incentives of exchange at arm's length are desired. The next step is therefore to analyze the coinparative benefits of administered versus negotiated pricing for parent-subsidiary transactions.

\section{Negotiated, Market-Based Transfer Pricing}

A planitiff challenging parent-subsidiary differential pricing under the Robinson-Patman Act claims that a favored subsidiary pays less to the seller than do the seller's outside customers. The statute implies that the subsidiary should be required to pay the inarket price if the court judges it to be a different purchaser. From the point of view of sound firm manageinent, however, it might not inake sense for the parent to charge the subsidiary a market-based transfer price for a particular product.

Transfer prices based on inarket rates provide incentive benefits for the firm. Subsidiary managers who are judged on profits have incentives to control costs in the absence of a break on imput prices from the parent firm. From the parent's poimt of view, if the subsidiary can purchase imputs elsewhere and the parent charges the market rate, the parent firm has imcentive to meet the competition in nonprice performance areas such as quality and delivery.

Incentives for the subsidiary to operate efficiently are not the only benefits of market-based intraenterprise pricing. When internal prices reflect market-price fluctuations, both the parent and subsidiary will adapt their input and output decisions accordingly. Because subsidiary managers with profit responsibility are not imsulated from the market when they pay market-based prices to the parent, the subsidiary will adapt "autonomously" 144 without involving company headquarters in its imput decisions.

143. See supra text accompanying notes 102-05.

144. See F.A. Hayek, The Use of Knowledge in Society, 35 Am. Econ. Rev. 519, 526-28 (1945) (discussing how the price system causes people to adapt efficiently without centralized coordination). 
There is a second kind of adaptation, however, for which marketbased transfer pricing does not help. An enterprise benefits from continuity of exchange between the parent and subsidiary for certain transactions, perhaps because it has invested much in the transactions or because the transactions are part of a long-term firm venture. If the exchange relationship between parent and subsidiary breaks down or conflict arises, maintenance of the transaction can require negotiation and concessions by both sides. When the parent firm anticipates such hazards, it may want to control the subsidiary's actions in the particular transaction even if it does not have general "dominion and control" over the entity. Market-based transfer pricing can make this difficult.

For example, consider a subsidiary that agrees to purchase imputs at market price from a division of the parent firm. Headquarters evaluates managers of both the subsidiary and the parent firm on the profits earned by their unit of the enterprise. If there is a supply shock of some kind in the input market, the market price will increase. Although the parent division's costs have not increased, it can take advantage of the short-run price rise to increase profits. Headquarters, however, might have different ideas. The parent firm took on risk by assuming full ownership of the subsidiary. Headquarters might decide that it would be better for the viability of the subsidiary, and for good relations with the subsidiary's managers, to keep charging the subsidiary the old input price. This decision, however, can create friction with the manager of the division of the parent firm that sells to the subsidiary because her profit scorecard will not look as good as the market allows. To enhance profits, the selling division might try to cheat to raise its performance evaluation despite the price constraint imposed by top management. For example, the affected division might cut back on costly performance areas such as quality and dehivery.

Under market-based transfer pricing, selective intervention by headquarters ${ }^{145}$ for purposes of mediating and adaptimg exchange with its subsidiary is costly. The very profit incentives that encourage efficient production and adaptation to factor and product market fluctuations make market-based transfer pricing difficult. This analysis suggests, therefore, that market pricing of parent-subsidiary transactions is best employed to maximize profit incentives when bilateral adaptation is relatively less valuable.

\section{Administered, Cost-Based Transfer Pricing}

There are transactions for which firms can foresee the need to coordinate exchange. These include transactions in which the enterprise

145. See generally ECONOMIC INSTTTUTIONS, supra note 122, at 135-37 (discussing the costs of selective intervention). 
gains by having both the parent and subsidiary take risks and make investments that potentially benefit the entire enterprise. For example, a parent firm might have the option of tailoring a product, distribution channel, or other asset to the needs of its subsidiary, or alternatively producing generic goods or services for the open market. If the specific investment $\mathrm{m}$ tailoring the good or service is efficient for the firm-that is, if it raises the joint economic returns to the parent and subsidiarythe parent will want to make the investment.

There is, however, some risk. To the extent that the tailoring is costly, the parent will lose its investment if the subsidiary elects to purchase from an outsider. Therefore, to create incentives for the parent and subsidiary to coordinate exchange, top management can mandate that the subsidiary purchase from the parent, but in return set a transfer price that approximates production cost. ${ }^{146}$ To the extent that cost is less than market price for a comparable good or service, the subsidiary has an incentive to cooperate. At the saine time, the parent is assured of covering the costs of tailoring its output. The parent firm therefore makes the specific investment, and the enterprise as a whole is better off.

As a second exainple, consider a parent firm that would like its subsidiary to invest in a particular project, such as a new product line. Suppose the subsidiary management's performance is evaluated on profits. To encourage subsidiary participation, the parent firm can guarantee to supply it with an input essential for the success of the venture. If the input market is subject to uncertainty and fluctuation, transferring the mput at market price might be a disincentive for the subsidiary to invest in the project despite its potential benefits. At market pricing, costs that rise suddenly put the subsidiary's investment at risk. An administered transfer price, however, protects the subsidiary's investnient in the venture against market fluctuations and eases the parties' exchange relationship.

Yet such nonmarket, administered pricing (usually cost-based) has a major drawback: profit-maximizing incentives are relatively weak under such a regime. Inducing subunits that have been organized into virtually autonomous profit centers to behave in a coordmated manner can involve difficult trade-offs. Professors Holmstrom and Tirole noted that integrated firms face the puzzle of selective intervention in that they would like to intervene to coordinate exchange without simnltaneously weakening perfornance incentives. ${ }^{147}$

There is, however, a fundamental trade-off: the firm cannot increase incentives for the subunits to cooperate without reducing the profit-mak-

146. See Eccles \& White, supra note 102, at $\mathbf{S 2 5}$ (discussing mandated full-cost transfers).

147. Holmstrom \& Tirole, supra note 130, at 4-5. 
ing incentives of a inarket-price regime. ${ }^{148}$ One reason why coordination coines at the expense of incentives when parent-subsidiary prices are cost based rather than market based is that when transfer prices are adininistered, the purchasing party generally does not have the option of looking outside the firm to buy the particular good. ${ }^{149}$ The seller's performance is then no longer linked to the market, reducing incentives for the seller to beat the market in order to gain the subsidiary's business. Moreover, the buyer is also insulated from the market price, and is therefore less disciplined in keeping its costs down. When the benefits of coordination offset weakened performance incentives, administered, nonmarket transfer pricing is advantageous.

\section{Predicted Alignments Between Pricing Policies and Transactions}

The above discussion described how the coniparative advantages of administered and market-based transfer prices depend on the nature of the transaction being inediated. Market-based prices help to inject the profit-1naximizing incentives of the market into intraenterprise transactions. They are desirable when it is best for the firm to have each subunit behave in a purely self-interested manner and when coordination and adaptation to changed circumstances are less important. Administered transfer pricing sacrifices high-powered market incentives but is beneficial when the need for coordinated adaptation by the trading parties is anticipated.

In hight of the variables that affect transaction costs, market-based transfer prices are arguably inost advantageous when conditions of asset specificity and uncertainty are relatively low. In such cases exchange is relatively simple, and the losses due to breakdown are more than offset by the benefits of high-powered, nnarket-like incentives.

When exchange requires specific investment or involves substantial uncertainty, however, two things happen. First, the possibility of opportunistic behavior increases. ${ }^{150}$ Second, there is heightened concern over future contingencies because there is value in maintaining exchange and in providing incentives to make specific investments in the exchange relationship. The benefits of high-powered market incentives can be offset by the difficulty and costs of governing exchange in the postcontracting period. In this case, administered, nonmarket transfer prices should be observed.

When prices are cost based, divisions act in a more integrated fashion, allowing greater intervention by central manageinent to coordinate adaptation to change. It is critical to note that the firm makes its deci-

148. See Economic InstrTutions, supra note 122 , at 140.

149. Holmstrom \& Tirole, supra note 130 , at 3.

150. See Economic InSTITUTIONS, supra note 122, at 47-49. 
sion at the transaction level. Although the subsidiary might be a fairly independent corporation with its own control systeins, board of directors, and officers, the parent might choose to sell to the subsidiary using a nonmarket pricing inechanisin to inake exchange inore flexible. To do this is, as the City of Mt. Pleasant court put it, to reap "the fruits of vertical integration." 151

\section{E. Evidence That Transaction-Level Factors Align Systematically with Transfer-Pricing Policies}

The next question is whether the predicted alignments between the factors that raise transaction costs and the choice of a pricing inechanisin actually exist. Transaction-level data on transfer pricing is extreinely hard to coine by. Several case studies based on intervicws and observations of firm practices have been published. ${ }^{152}$ While those studies afford some insight into the intricacies of intraenterprise transactions, they are insufficiently microanalytic for the purpose of finding transaction-level alignments. Researchers looking deeper into this problein must therefore start from scratch and assemble data theinselves.

\section{Statistical Data}

I recently conducted a detailed study of internal transactions at a major, decentralized high technology firm. ${ }^{153} \mathrm{I}$ interviewed managers about intcrdivisional sales in gencral and about specific component transactions. I then obtained detailed data for sixty-one components sold between subunits of the firm. ${ }^{154}$

Two caveats about this study are in order. First, the data presented coines from transactions between divisions of the firm, not from sales to or between separately incorporated subsidiaries. Because only the latter are at issue for the Robimson-Patman Act, the data is not perfectly on point. The results, however, are still relevant. The company at issue organizes its divisions into virtually autonounous groups, each having its own manageinent structure, research-and-development facilities, and substantial operating independence. They are, therefore, similar to separate entities. Given this, there is no reason to beheve that the results cannot also inform our understanding of parent-subsidiary exchange.

151. City of Mt. Pleasant v. Associated Elec. Coop., 838 F. 2d 268, 279 (8th Cir. 1988).

152. See generally Eccles, supra note 3, at $40-49$ (discussing results of the few studies with transaction data for transfer pricing).

153. Howard A. Shelanski, Transfer Pricing and the Organization of Internal Exchange (Dec. 1990) (unpublished paper, presented at the Workshop on Institutional Analysis, U.C. Berkeley, on file with author). Note: the formal statistics are not contained in the paper cited above. They are presented for the first time in this Comment. See infra text accompanying notes 159-64.

154. I use the term "components" generically to refer to inputs or subparts used to produce a final product. 
Second, the difficulty of obtaining data has constrained the analysis to one case study for the purposes of this Comment. One must be cautious in generalizing from one set of observations. Before the results presented below can be considered conclusive, further studies will have to be done. My goal is simply to present one round of evidence to support the transaction-cost argument. I thus offer the results as suggestive and compelling evidence, not as conclusive proof.

I gathered data by having people at one of the company's manufacturing sites fill out a survey for each of sixty-one components. ${ }^{155}$ The survey first asked what transfer-pricing pohcy was used for the itein's intraenterprise sale. It then explaimed several variables that affect transaction costs: asset specificity (both physical and human), ${ }^{156}$ design complexity, quality requirements, and research-and-development requirements. The company representatives were asked to rate each component as to the presence of each factor. For example, the survey asked whether specific capital investment in production of the given component was high, inedium, or low. I divided the completed surveys into groups according to the transfer-pricing inechainism used and estimated the effects of the transaction-cost variables on the firm's choice of transfer-pricing pohicy. ${ }^{157}$

The company that I studied used three transfer-pricing policies for intraenterprise sales. Two of the pohicies were administered and required different prices for inside and outside customers. These were cost-based and equal-profit-inargin (EPM) ${ }^{158}$ transfer prices. The third pohicy was negotiated, market-based pricing. For analytic purposes, I divided the pohicies into two categories: administered, which included cost-based and EPM pricing (forty observations), and negotiated, which included inarket-based pricing (twenty-one observations).

Of the components transferred under negotiated pricing, company officials rated $38 \%$ as highly complex, $38 \%$ as moderately complex, and $24 \%$ as noncomplex. None required high specific capital investment, $43 \%$ required moderate levels of specific physical capital, and $57 \%$ required very low specific capital imvestment. Fimally, of these same components, $5 \%$ required high investment in specific human skills, $38 \%$ required moderate levels, and $57 \%$ required low levels of human capital investment.

The components transferred under administered transfer pricing

155. This technique has been used successfully in several economic studies. See, e.g., Masten, supra note 134 , at $407-09$.

156. Asset specificity can appear in several forms. Physical asset specificity refers to things such as unique machinery. Human asset specificity refers to training and skills that have no alternative use value.

157. Shelanski, supra note 153 , at 52 .

158. See supra note 97 and accompanying text (describing EPM pricing). 
policies show a different trend. Company officials rated $42.5 \%$ as highly complex, $42.5 \%$ as moderately complex, and $15 \%$ as noncomplex. With respect to specific investment in physical capital imputs, $17.5 \%$ required high levels, $82.5 \%$ required moderate levels, and none could be produced with low levels of such investment. Finally, production of $32.5 \%$ of these components required high levels of component-specific human skills, $62.5 \%$ required low levels, and only $5 \%$ could be made witl low levels of specific human capital investment.

In general, the variables that TCE predicts will raise the costs of governing exchange correlate more highly with components transferred under administered pricing than they do with components sold at market-based transfer prices. These preliminary results offer some support for the role that transaction-cost economizing plays in determining transfer-pricing policy. Yet correlations are extremely weak tests. The analysis that follows uses qualitative-choice model statistical estimation to provide a more rigorous causal analysis of the effect of the TCE variables on transfer pricing.

\section{Statistical Estimation}

The next step in the empirical analysis is to measure whether the independent variables are statistically significant ${ }^{159}$ factors in the choice between administered and negotiated transfer-pricing policies. To do this, I tested three hypotheses:

H1: As the complexity of a component imcreases, asset specificity held constant, the likelihood of an administered transfer price decreases. This is predicted because complexity raises the information required for administering a transaction. Because such inforination is concentrated at the divisional level, central management will be less able than the divisions to construct an effective pricing policy. So where complexity alone exists-without raising asset specificity-negotiated pricing is more likely. ${ }^{160}$

H2: As the amount of skills training specific to the production of a particular component (human asset specificity) imcreases, so does the likelihood of observing an administered transfer-pricing policy.

H3: As the amount of capital imvestment specific to the production

159. By convention, a variable is statistically significant if one can be $95 \%$ certain that the coefficient on the variable is not zero. This is referred to as testing significance at the $5 \%$ level and is accomplished by constructing a $95 \%$ confidence interval around the variable's measured coefficient. If that interval does not contain zero, the variable is "statistically significant." See THOMAs H. WONNACOTT \& RONALD J. WONNACOTT, INTRODUCTORY STATISTICS FOR BUSINESS AND ECoNomics 260 (3d ed. 1984); Robert S. Pindyck \& DaNiel L. Rubinfeld, Econometric MODELS \& ECONOMIC FoRECASTS 36-38 (3d ed. 191).

160. This accords with the rationale behind the M-form firm structure: it is efficient because central management devotes its energies to long-term management, while short-term operating decisions are decentralized at the division/subsidiary level where knowledge and expertise concentrate. 
of a particular component (physical asset specificity) increases, so does the likelihood of observing an administered transfer-pricing policy.

I tested these hypotheses using the logit estimation technique. ${ }^{161}$ Logit is an appropriate technique when the dependent variable in the model takes on discrete, qualitative values. In this study, the dependent variable is transfer-pricing policy, which can take on only two qualitative values: administered or negotiated. I am therefore measuring the effect of the independent variables (complexity, human asset specificity, and physical asset specificity) on a discrete, binary choice. ${ }^{162}$ I estimated the following equation:

(Logit) $\mathbf{T P}=b_{1} c+b_{2}$ COMP $+b_{3}$ HSPEC $+b_{4}$ PSPEC $+e$ where the $b_{i}$ 's are coefficients, and:

TP $=$ transfer-price policy; $\mathbf{T P}=1$ if administered, and $\mathrm{TP}=0$ if negotiated.

c $=$ constant term (a vector of 1's).

$\mathrm{COMP}=$ component complexity; $\mathrm{COMP}=0$ if low, 1 if medium, and 2 if high.

HSPEC $=$ human-asset specificity; HSPEC $=0$ if low, 1 if medium, and 2 if high.

PSPEC = pliysical-asset specificity; PSPEC $=0$ if low, 1 if medium, and 2 if high.

e $\quad=$ random error effect from unobserved variables.

The results of the logit estimation are shown im the table below and in the following equation:

$$
\mathrm{TP}=-5.66^{*} \mathrm{c}-\underset{(-2.00)}{2.20 * \mathrm{COMP}}+\underset{(1.32)}{1.31 * \mathrm{HSPEC}}+\underset{\mathbf{1}}{9.15 * \mathrm{PSPEC}}
$$

The numbers in brackets are the t-statistics ${ }^{163}$ for the coefficients. A tstatistic of approximately 2.00 shows statistical significance for the variable at the $5 \%$ level-that is, we are $95 \%$ certain that the coefficient value is not zero.

161. See Kenneth Train, Qualitative Choice ANalysis ch. 2 (1986)

162. Other examples of qualitative-choice decisions are whether people will vote yes or no on a given issue as a functiou of certain factors, or whether, given certain variables, people will or will not buy a new car. Contrast this with studies where the dependent variable is continuous: for example, consumption as a function of income and age. Consumption can take on continuous dollar values and is not discrete or qualitative. Logit is not appropriate for such estimation.

163. The t-statistic is used to calculate confidence intervals. It is determined by dividing the coefficient of a variable by the variable's standard error. 
REGRESSION RESULTS

\begin{tabular}{|c|c|c|c|c|}
\hline \multicolumn{5}{|c|}{$\begin{array}{l}\text { Dependent variable is TP } \\
\text { Number of observations: } 61\end{array}$} \\
\hline VARIABLE COEF & EFFICIENT & STD. ERROR & Г-STAT. & 2-TAIL SIG. \\
\hline C & -5.65 & 4.29 & -1.31 & 0.19 \\
\hline COMP & -2.20 & 1.09 & -2.00 & 0.05 \\
\hline HSPEC & 1.31 & 0.99 & 1.32 & 0.19 \\
\hline PSPEC & 9.14 & 4.68 & 1.95 & 0.05 \\
\hline Log likelihood & -18.16 & & & \\
\hline Cases with $\mathrm{TP}=1$ & 40 & & & \\
\hline Cases with $\mathrm{TP}=0$ & 21 & & & \\
\hline VARIABLE & MEAN & MEAN WHEN TP=1 & \multicolumn{2}{|c|}{$=1 \quad$ MEAN WHEN TP=0 } \\
\hline C & 1.00 & 1.00 & \multicolumn{2}{|r|}{1.00} \\
\hline COMP & 1.22 & 1.27 & \multicolumn{2}{|r|}{1.14} \\
\hline HSPEC & 1.00 & 1.27 & \multicolumn{2}{|r|}{0.47} \\
\hline PSPEC & 0.91 & 1.17 & \multicolumn{2}{|r|}{0.42} \\
\hline
\end{tabular}

The results show that the hypothesis about complexity (H1) cannot be rejected. Standing alone, complexity has a negative and significant effect on the possibility that a manager will choose an administered, nonmarket transfer price. Hypothesis 2, concerning human asset specificity, is rejected. Though the statistical effect is positive, as predicted, the effect is not significant at the $5 \%$ level. The t-statistic of 1.32 allows us to be only $80 \%$ certain that the coefficient on HSPEC is not zero. ${ }^{164}$ The third hypothesis, about physical asset specificity, cannot be rejected. Significance exists at the $5 \%$ level. In addition, the effect of physical asset specificity on the likelihood of choosing an administered transfer price is very large, as shown by the coefficient of 9.15 on PSPEC. Even an intermediate level of physical asset specificity will substantially raise the probability of observing an administered transfer price.

The results of the statistical estimation show that, in this case study, the nature of the component being transferred and factors relating to its production significantly affect manageinent's choice of transfer-pricing policy for individual transactions. Though human capital specificity did not have a significant effect in iny sample, both physical asset specificity and component coinplexity significantly affected intraenterprise pricing. This data supports the general proposition that differential pricing in parent-subsidiary sales reflects transaction-cost concerns. The case study provides evidence that admimistered, nonmarket pricing most likely occurs when those concerns are strongest-in transactions supported by high, relationship-specific investment, when the inability of central man-

164. Pindyck \& Rubinfeld, supra note 159 , at 563. 
agement to coordinate adaptation could lead to net loss for the firm in the face of unforeseen contingencies.

\section{Evidence from Interviews with Managers}

Anecdotal evidence in economics or policy analysis is never dispositive. This does not mean, however, that it is unimportant or useless. On the contrary, it is often richer and inore detailed than "formal" data. The interview evidence presented below coinplements the statistical data and offers insight into why choosing pricing pohicies for parent-subsidiary transactions is so complicated.

The first interview was with the controller for a group consisting of several wholly owned divisions and subsidiaries of the company. $\mathrm{He}$ made several observations that support the hypothesis that market-based and administered transfer-pricing policies have distinct advantages depending on the transaction. ${ }^{165}$ The controller stated that he viewed transfer pricing as a task that often required a "cultural choice."166 $\mathrm{He}$ could "lean on buyers and sellers to accommodate each other," injecting authority into the process. Alternatively, he could "let independent managers inake choices" and keep his office out of the transaction. ${ }^{167}$

The controller stated that "fairness, efficiency and peace in the family are all legitimate goals" of transfer pricing. ${ }^{168}$ In choosing an approach for a particular transaction, he engaged in "a balancing of inanagerial incentives" that took into consideration not ouly the attributes of the transaction but also the personalities of the subumit parties involved. ${ }^{169}$ As a general rule, however, he found that there was always tension between the goals of "peace in the family" and efficiency in setting transfer-price pohicies for the suburits in his group. ${ }^{170}$

His experience as a controller taught him that full-cost pricing had "peace in the family" advantages and was the inost common policy for specialized goods that were "not interchangeable with other products."171 The downside, however, was that "inanagerial incentives suffer, hurting worldwide competitiveness."172 The company, therefore, tried to use market-based prices when it could. ${ }^{173}$ The controller stated, however, that inarket pricing was easiest for generic commodities, and said that "there is a $90 \%$ chance we won't make a commodity-like product"

165. Shelanski, supra note 153, at 28-35 (describing and analyzing first interview).

166. Id. at 30 .

167. Id.

168. Id. .

169. Id.

170. Id. at 35 .

171. Id. at 29.

172. Id.

173. Id. at 28-29. 
for internal sale. ${ }^{174}$

Other company officials echoed these views. The controller of another group within the company also praised the incentive properties of market-based transfer pricing. ${ }^{175} \mathrm{He}$ felt, however, that inarket-based pricing was most sensible for internal sales of "generic products," while more complex components tended to be transferred at some mandated rate based on cost. ${ }^{176} \mathrm{~A}$ divisional manager present at this second interview agreed that transferring specially produced goods at cost helped keep peace in the family. ${ }^{177}$ This controller added that he could get sellmg subuints to cooperate with buying subunits' special requirements under an administered price regime. ${ }^{178}$

The interview evidence supports the transaction-cost theory in two ways. First, managers do face a trade-off between efficiency incentives and bilateral coordination in choosing a pricing policy for interdivisional or parent-subsidiary transactions. Second, more complex transactions involving nonstandard products often are more easily managed through cost-based transfer pricing. Although the company officials liked the incentives provided by market pricing, they found that pohicy most feasible for sales of generic products.

The interviews also revealed that more arbitrary and idiosyncratic considerations play a role in the pricing of transactions. This fact was best expressed by the first controller interviewed: "the essence of transfer pricing is that it involves several vectors not isolable from each other."179 Some of these vectors were "history, industry practices, product maturity, efficiency, organizational boundaries, and performance measures."180 The interviews therefore confirmed what the statistical data revealed: although transaction-level factors are not fully determinative, they have observable and systematic effects on the choice of a transfer-pricing mechanism.

\section{$\mathrm{V}$ \\ The Policy Debate Revisited}

This Part addresses how the managerial purposes of transfer pricing and the transaction-cost analysis inform the choice between the smgleentity rule and the dominion-and-control test. The multiple purposes of internal pricing indicate that courts must be cautious when interfermg

174. Id. at 29.

175. See id. at 38 (expressing that managerial incentives were a problem with cost-based pricing).

176. Id. at 36-37.

177. Id. at 42.

178. Id.

179. Id. at 36.

180. Id. 
with intraenterprise transactions. Although the criteria of efficiency, momitoring, and fairness can conflict with each other, they share one trait: they all require im many circumstances that the internal price differ from the market price charged by the firm.

Requiring parent firms to charge subsidiaries the same price that they charge outsiders can mterfere with a variety of legitimate managerial efforts. Crafting efficient organizational control and incentive systems will be inore difficult within complex enterprises. While theoretically possible to distinguish legitimate inanagerial goals from anticompetitive strategies, doing so in practice is difficult. Moreover, it would be both burdensome and arbitrary for courts to attempt such judgments. This suggests that extension of the Act to parent-subsidiary transactions would reach the point where the costs from enforcement exceed any benefits of the statute.

The dominion-and-control test has the apparent virtue of applying the Act only when legitimate managerial concerns are absent. On a general level, one could argue that those concerns are never absent when a firm takes on the risk of owning a subsidiary. Yet that argument makes the determination hinge on ownership alone, a stance that may have merit but does not directly address the dominion-and-control test.

Of greater consequence for the dommion-and-control test is the evidence that transaction-level factors affect the efficient choice of transferpricing policy. The statistical analysis of my data confirms that specified transaction-level variables significantly affect the choice of transfer-pricing policy. The interviews corroborate the statistical results and show that idiosyncratic considerations also affect the variation in observed transfer prices. The primary implication of these findings is that the broad indicators used by courts to determine dominion and controloverlapping boards and officers, shared accounting systeins and facilities, and control of pricing pohicies-are likely to be misleading about whether a particular transaction warrants a differential internal price. Firns can have valid reasons for exercising dominion and control over selected transactions with subsidiaries even when they do not retain general operating control over the subsidiary.

An example inay clarify this point. Suppose a parent firm purchases or establishes a subsidiary. At the time the firm makes the initial investinent, it also makes certain organizational decisions such as whether to separately incorporate the subsidiary or to share personnel and control systems. Suppose the firm decides to organize the subsidiary as a virtually independent corporation. A court applying the dominion-and-control test will find differential pricing to be illegal for all sales the firm nakes to the subsidiary.

On the other hand, transaction-cost analysis would argue for 
allowing differential pricing. After the basic organizational decisions are in place, the parent and subsidiary might engage in transactions that are most efficiently mediated by an administered pricing inechanism. For any given transaction, the firm will not find it worthwhile to reorganize the basic control structure of the subsidiary. Application of the dominion-and-control test will inake the resulting differential pricing illegal even though it is efficient and beneficial for the firm.

The evidence presented supports the role of transaction-level factors in determining transfer-pricing policy for a given exchange. Because the dominion-and-control test focuses on macro-level indicators, it will miss reasonable exercises of authority over individual transactions. Yet the evidence also indicates that there is no feasible way for the dominionand-control test to take micro-level factors into account to determine whether the subsidiary is a different purchaser under the Act for a given transaction. The presence of factors imcreasing transaction costs is hard to assess and subject to dispute. Even if they could be judged rehably, the interviews show that variables such as asset specificity and complexity do not completely determine the efficient transfer-pricing decision. There is no way for a court to judge the idiosyncratic factors that come into play.

\section{A. Policy Recommendation}

The TCE analysis implies that the single-entity rule is the best policy to apply to differential pricing between parent firms and subsidiaries. Where a subsidiary is wholly owned, parent-subsidiary "sales" should not be subject to Robinson-Patman scrutiny; the subsidiary should never qualify as a "different purchaser" under the Act.

The reasoning leading up to this recominendation differs from the justifications courts have used previously to reach the same conclusion. ${ }^{181}$ The justification for the single-entity rule is neither that internal prices have no economic effect nor that firms always act reasonably and efficiently. Rather, transfer prices are important for the economic organization of complex enterprises, and managers will usually try to choose the pricing mechanism that economizes on transaction costs.

There unquestionably will be instances in which a parent firm uses its subsidiary in a predatory manner. Courts cannot, however, reasonably distinguish predatory differential pricing from legitimate management of a particular transaction. Dominion-and-control test advocates warn that courts will make mistakes. On the other hand, courts will make many more mistakes if they begin to inquire into an enterprise's transfer-pricing decisions. ${ }^{182}$

181. See supra text accompanying notes 53-72.

182. The analysis in this paper is directed only at the case of wholly owned subsidiaries. Many 


\section{B. Remaining Problems and Possible Limitations of the Analysis}

The policy recommendation does not imply that predatory conduct should be left unregulated. Rather, this problem simply should not be addressed at the level of transfer-pricing policy. The plaintiff can still challenge true predatory pricing by the subsidiary-pricing below the average variable cost of production ${ }^{183}$ - under the Sherman Act. ${ }^{184}$ Perhaps adoption of the simgle-entity rule therefore should be coupled with stronger Slierman Act scrutiny of subsidiary behavior in order to regulate predatory conduct more effectively. ${ }^{185}$

While the arguments in this Comment are aimed at all types of intraenterprise transfers, they may apply more directly to some contexts than to others. The use of transfer pricing to control individual component transfers in an industrial firm is verifiable. Some miglit suspect, however, that the organizational rationale for transfer pricing is less tenable when a manufacturer transfers finished goods to a distribution or retail subsidiary. There is substantial evidence, lowever, that transaction-cost considerations are important even $\mathrm{m}$ the distribution and retailmarketing context. ${ }^{186}$ While the recommendation for a single-entity rule might appear inost compelling for industrial component transfers, the rule sliould be applied to all parent-subsidiary sales challenged under the Act. Strong evidence that the rule is madequate should be required before any exceptions to its consistent application are considered.

of the arguments and conclusions could have some bearing as well on cases involving partially owned subsidiaries, franchises, independent long-term contractors, and similar entities. Transactioncost analysis differs somewhat for these kinds of organizational structures. Other economic and policy considerations also differ once the analysis moves beyond the complete-ownership case. Elaboration of these points is beyond the scope of this Comment. While the analysis above could have limited application to other economic arrangements, any such extension is unintended and unwarranted without further analysis.

183. 3 Phillip AReeda \& Donald F. Turner, ANTitrust law: AN ANalysis of ANTITRust PRinciples aNd Their Application, I 715c-d (1978).

184. 15 U.S.C. $\S 2$ (1988) (prohibiting the monopolization of markets).

185. In predatory-pricing cases, the courts look at the summed costs of variable inputs and divide by the output to determme average variable cost. If the price is less than that average cost measure, the firm is generally in violation of the law.

If the single-entity rule were umiversally adopted, courts should not let subsidiaries list the price they pay to parent firms as the cost of internally procured inputs, because if that price is below cost-allowable under the single-entity standard-predatory pricing by the subsidiary will go unrecognized. Courts should use the parent firm's production costs for any inputs the subsidiary purchases when judging the latter's market behavior. This allows the enterprise to transfer-price as it likes but still affords competitors protection from predatory pricing.

186. See Shelanski, supra note 132, at 11-13. Further discussion of this point is beyond the scope of this Comment and is the subject of research in progress. 


\section{VI}

\section{CONCLUSION}

The application of the Robinson-Patınan Act to parent-subsidiary transactions is an unsettled area of the law. The statute itself is ambiguous about whetlier such sales fall within the Act. The federal circuits are divided on whether to use the single-entity standard or the dominionand-control test. This Comment has argued that pricing between subunits of a firm-transfer pricing-is a complex managerial task that serves the purposes of efficiency, monitoring a subsidiary's performance, and keeping "peace in the family." Further, and more importantly, it has used transaction-cost economics to show that transfer-pricing policy can be a function of individual transaction characteristics. Therefore, the intraenterprise price can reflect efforts to economize on the costs of governing the particular transaction, quite apart from any anticompetitive intent.

The dominion-and-control test does not and feasibly cannot examine transaction-level factors. The test therefore neglects the true organizational miportance of transfer pricing and will lead to perverse outcoines. In addition, a firm can escape the consequences of the Act by reorganizing its subsidiary or by conferring benefits through means otler than price. Despite these drawbacks, the dominion-and-control test lias proponents, and the debate contimues.

This Comment has not rehed on arguments based solely on ownership to reach its result, although such arguments might have merit. Rather, it has attempted to meet the dominion-and-control test on its own terms. Even if dominion and control should determine when the Act applies, a firm might exercise authority at the transaction level ratler than through broader control of the subsidiary. This makes the test improper im its current form and unmanageable for courts at any greater level of detail. Despite its potential problems, the single-entity standard sliould therefore prevail, and wholly owned subsidiaries should not be considered different purcliasers under the Robinson-Patman Act. 
